\section{Pediatric Endocrinology Diabetes and Metabolism}

In memoriam | Wspomnienie

Pediatr Endocrinol Diabetes Metab 2020; 26 (2): 63-64 DOI: https://doi.org/10.5114/pedm.2020.96162 www.pteidd.pl

\title{
In memoriam of Professor Maria Rybakowa
}

\author{
Profesor dr hab. Maria Rybakowa - wspomnienie
}

It was my great honour and privilege to spend 6 years working as an assistant to Professor Maria Rybakowa in the Department of Children and Youth Endocrinology at the Institute of Paediatrics in Krakow, which she founded in 1984, and managed for 10 years as its first head.

Based on her immense knowledge in the fields of paediatrics and endocrinology, which she acquired from the most eminent experts in these disciplines, Professor Maria Rybakowa was an accomplished and respected mentor to all the assistants in the Department. Throughout her scientific career, she met a number of foremost authorities in her field of interest, including Professor Lelong, one of the founders of neonatology; Professors Fanconi and Crigler, the founders of modern paediatrics; Professor Tanner and his assistant Professor Whitehouse, the

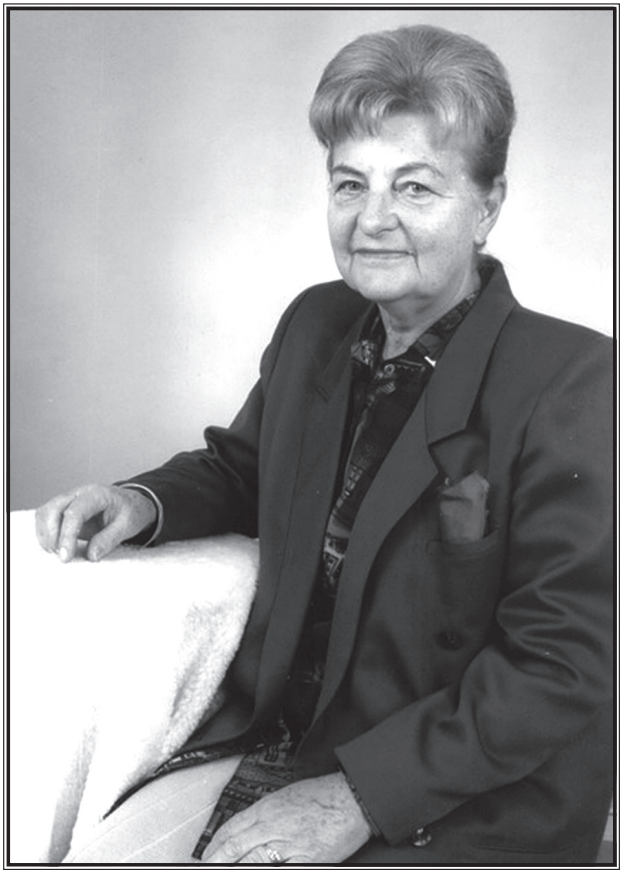

Miałem ogromne szczęście i przywilej być przez 6 lat asystentem Pani Profesor Marii Rybakowej w Klinice Endokrynologii Dzieci i Młodzieży w Instytucie Pediatrii w Krakowie, którą założyła w 1984 roku i której była pierwszym kierownikiem przez 10 lat.

Wszyscy asystenci Kliniki mogli uczyć się od Niej pediatrii i endokrynologii, bowiem Pani Profesor Maria Rybakowa posiadała ogromną wiedzę zdobytą od sław pediatrii i endokrynologii. Na swojej drodze naukowej spotkała: profesora Lelonga - jednego z twórców neonatologii, profesorów Fanconiego oraz Criglera - twórców współczesnej pediatrii, prof. Tannera i jego asystenta prof. Whitehouse'a - twórców auksologii, prof. Pradera uważanego za ojca światowej endokrynologii dziecięcej, oraz prof. Pawlikowskiego - niekwestionowanego ojca endokrynologii polskiej. founders of auxology; Professor Prader, recognised as the founding father of paediatric endocrinology; and Professor Pawlikowski, the undisputed founding father of Polish endocrinology.

For many years, she was friends with Thomas P. Foley, Professor in Paediatrics at the University of Pittsburgh School of Medicine, and Chief in the Division of Endocrinology at Children's Hospital of Pittsburgh, USA. Their friendship resulted in 13-year collaboration between both medical centres, and training programmes in Pittsburgh offered through the Project Hope Foundation to the majority of the Department's assistants. Professor Rybakowa should be credited for teaching us synthetic and deductive reasoning in the practice of medicine. She was a great believer in the maxim that there is not a single idea however innovative it might be - that could not be summed up in a single sentence. Today, however, I have difficulty encapsulating in one sentence the contribution made by Professor Maria Rybakowa to the development of paediatric endocrinology. Perhaps her role can best be described as "the founding mother of Polish and co-founder of international paediatric endocrinology". She herself, as a woman, greatly appreciated the title of "The First Lady of Polish Endocrinology", as she used to be called in the scientific community.

There is no doubt that Professor Rybakowa deserved these accolades. As a member of the working group on neonatal
Przez wiele lat przyjaźniła się z prof. Thomasem P. Foleyem, dyrektorem Uniwersyteckiego Szpitala Dziecięcego i kierownikiem Kliniki Endokrynologii w Pittsburghu, USA. Zaowocowało to 13-letnią współpracą obu ośrodków oraz pozwoliło większości asystentów Kliniki szkolić się w Pittsburghu w ramach fundacji Project Hope. Pani Profesor uczyła nas także syntetycznego i dedukcyjnego myślenia lekarskiego. Sama wyznawała maksymę, że nie ma takiej, nawet najbardziej nowatorskiej myśli, której nie dałoby się ująć jednym zdaniem. Dzisiaj jednak mam trudność w określeniu jednym zdaniem roli, jaką odegrała Profesor Maria Rybakowa w rozwoju endokrynologii dziecięcej. Może takim, że „była matką polskiej i współtwórczynią światowej endokrynologii dziecięcej". Sama, jako kobieta, bardzo ceniła sobie nadany jej i krążący w środowisku naukowym tytuł „Pierwszej damy polskiej endokrynologii dziecięcej”.

Istnieją liczne dowody, że są to tytuły należne. Jako członek grupy ds. badań przesiewowych wrodzonej niedomogi tarczycy przy Europejskim Towarzystwie Endokrynologii Dziecięcej (ESPE), a także Rady Kontroli Zaburzeń z Niedoboru Jodu w Europejskim Towarzystwie Endokrynologicznym (ESE) oraz przewodnicząca grupy pediatrycznej Polskiej Komisji Kontroli Chorób z Niedoboru Jodu (PCC IDD), wprowadziła masowe badania przesiewowe wrodzonej niedomogi tarczycy u noworodków w południowo-wschodniej Polsce oraz współtworzyła 
screening for congenital hypothyroidism at the European Society of Paediatric Endocrinology (ESPE), and the Council for the Control of lodine Deficiency Disorders at the European Society of Endocrinology (ESE), and the chairwoman of the paediatric group of the Polish Council for the Control of lodine Deficiency Disorders (PCC IDD), she contributed to the introduction of neonatal mass screening for congenital hypothyroidism in south-eastern Poland, and co-created a system of obligatory iodisation of table salt in Poland. These measures saved many children from severe mental retardation. In her capacity as the chairwoman of the Human Development Committee at the Faculty of Medical Sciences of the Polish Academy of Sciences in Warsaw, she founded and headed the Commission on Endocrinology and Metabolism operating at the Committee. One of the activities of the Commission was the establishment of the Coordination Team for Growth Hormone Treatment. While heading the Paediatric Section at the Polish Society of Endocrinology (PTE), she co-originated the idea of transforming this entity into the Polish Society of Paediatric Endocrinology (PTED) (today the Polish Society of Paediatric Endocrinology and Diabetology) (PTEiDD), in which she served as a member of the Executive Board. With these initiatives, she consolidated and unified the community of paediatric endocrinologists, which is thriving today, and contributed to the development of the Polish school of paediatric endocrinology.

In recognition of her invaluable service to the fields of paediatrics and endocrinology, Professor Rybakowa received medals awarded by a number of national paediatric societies, including Albert Einstein Medal of the Swiss Society of Paediatrics, Jan Evangelista Purkyně Medal of the Czech Paediatric Society, Józef Brudziński Medal of the Polish Paediatric Society, and Tadeusz Pawlikowski Medal of the Polish Society of Paediatric Endocrinology

Professor Maria Rybakowa was and will always be present not only in our hearts and memories, but also in the everyday medical, scientific and teaching activities in the Children's and Youth Endocrinology Clinic which she created.

Prof. dr hab. med. Jerzy Starzyk Head of the Department of Children and Youth Endocrinology, Institute of Paediatrics, Jagiellonian University Medical College in Krakow system obligatoryjnego jodowania w Polsce soli kuchennej. Uratowało to wiele dzieci od ciężkiego niedorozwoju umysłowego. Będąc z kolei przewodniczącą Komitetu Rozwoju Człowieka Wydziału Nauk Medycznych PAN w Warszawie, powołała Komisję Endokrynologii i Przemiany Materii przy tym komitecie. Z komisji tej wywodzi się także Zespół Koordynacyjny ds. Leczenia Hormonem Wzrostu. Będąc przewodniczącą Sekcji Pediatrycznej przy Polskim Towarzystwie Endokrynologicznym (PTE), stała się wspótinicjatorką przekształcenia jej w Polskie Towarzystwo Endokrynologii Dziecięcej (PTED; dzisiaj Polskie Towarzystwo Endokrynologii i Diabetologii Dziecięcej PTEiDD), w którym pełniła następnie funkcję członka Zarządu Głównego. Tymi działaniami budowała i jednoczyła silne dzisiaj środowisko endokrynologów dziecięcych oraz tworzyła polską szkołę endokrynologii dziecięcej.

Za swoje zasługi w dziedzinie pediatrii i endokrynologii Profesor Maria Rybakowa została odznaczona medalami pediatrycznych towarzystw naukowych: szwajcarskiego im. Einsteina, czeskiego im. Purquiniego i polskiego im. Brudzińskiego oraz Medalem im. Pawlikowskiego PTED.

Pani Profesor Maria Rybakowa zawsze istniała i będzie istnieć nadal nie tylko w naszych sercach i pamięci, lecz także w codziennych działaniach lekarskich, naukowych i dydaktycznych w stworzonej przez nią Klinice Endokrynologii Dzieci i Młodzieży.

prof. dr hab. n. med. Jerzy Starzyk kierownik Kliniki Endokrynologii Dzieci i Młodzieży Katedry Pediatrii, Instytut Pediatrii, Collegium Medicum, Uniwersytet Jagielloński w Krakowie 